\title{
Effect of Mixing Ratio between Pork Loin and Chicken Breast on Textural and Sensory Properties of Emulsion Sausages
}

\author{
Hyun-Wook Kim, Min-Sung Choi, Ko-Eun Hwang, Dong-Heon Song, Yong-Jae Kim, Youn-Kyung Ham, \\ Seong-Jin Chang, Yun-Bin Lim, Yun-Sang Choi, and Cheon-Jei Kim* \\ Department of Food Science and Biotechnology of Animal Resources, Konkuk University, Seoul 143-701, Korea
}

\begin{abstract}
This study is conducted to evaluate the effects of the mixing ratio between pork loin and chicken breast for textural and sensory properties of emulsion sausages. Meat homogenates are prepared by using five mixing ratios between pork loin and chicken breast (100:0, 70:30, 50:50,30:70, and 0:100), and the emulsion sausages are also formulated with five mixing ratios. The additions of chicken breast increase the salt soluble protein solubility due to high $\mathrm{pH}$ levels of chicken breast, thereby resulting in the reduction of cooking losses. In addition, the apparent viscosity of meat homogenates increase with increasing amounts of chicken breast. In terms of emulsion sausages formulated with pork loin and chicken breast, the addition of chicken breast above $50 \%$ may contribute to a softer and more flexible texture of emulsion sausages. For sensory evaluations, an increase in the added amount of chicken breast contributes to a rich umami taste and deeper flavor within the emulsion sausages, resulting in the high overall acceptance score for the formulation of $0-30 \%$ pork loin and $70-100 \%$ chicken breast. Therefore, the optimal mixing ratios between pork loin and chicken breast are $0-30 \%$ and $70-100 \%$ for enhancing the textural and sensory properties of emulsion sausages.
\end{abstract}

Key words: chicken breast, emulsion sausage, pork loin, sensory characteristics

\section{Introduction}

The skeletal muscle, which has been widely used to manufacture several meat products, can be largely classified as red, intermediate and white muscle, depending on their muscle composition (Klont et al., 1998). Hämäläinen and Pette (1995) observed four different types of myosin heavy chain (MHC), including MHC type I, MHC type IIA, MHC type IIB and MHC type IIX, based on myofibrillar ATPase activity. Differences in the combination of these myofibrillar isoforms determined the muscle characteristics affecting meat quality, such as color, sensory satisfaction, tenderness and water holding capacity (Klont et al., 1998).

Chicken breast has received much attention from meat consumers and the meat industry as a healthy white meat serving low fat content. Further, pork loin, which is an intermediate muscle between red and white muscles, contains low fat content as compared to other pork parts (Dorado et al., 1999). According to Smith and Fletcher (1987),

\footnotetext{
*Corresponding author: Cheon-Jei Kim, Department of Food Science and Biotechnology of Animal Resources, Konkuk University, Seoul 143-701, Korea. Tel: 82-2-450-3684, Fax: 82-2-444-6695, E-mail: kimcj@konkuk.ac.kr
}

MHC type II or white fibers are the most fiber in chicken breast muscle (Musculus pectoralis major) regardless of age and sex. Meanwhile, pork loin (M. longissimus dorsi) consists of a high degree of MHC type IIB compared to MHC type I and IIA fibers (Karlsson et al., 1999). Although the two muscles similarly contain a high degree of MHC type II, there were great differences in the processing quality between the two muscles. For technologically manufacturing meat products, such as emulsion sausage, patty and restructured ham, the degree of myofibrillar protein solubility is the most important factor affecting gel formation in the final product (Asghar et al., 1985). The solubility of myofibrillar proteins, known as salt soluble protein due to its solubility in salt solution, was affected by the $\mathrm{pH}$ of raw material (Lesiów and Xiong, 2003), ionic strength and the condition of extraction (Gillett et al., 1977). Myosin, actin and actomyosin are major myofibrillar proteins in the skeletal muscle. Tsai et al. (1972) reported that myosin has an important role for the formation of emulsion stability compared to actin or sarcoplasmic protein. In addition, Lan et al. (1995) noted that the myofibrillar protein contents of pork, beef, chicken breast, chicken thigh and turkey breast were $11.41 \%, 12.65 \%$, $12.57 \%, 10.87 \%$, and $13.01 \%$, respectively, and suggested 
that the myofibrillar protein content was different from animal species and parts.

Recently, Zorba and Kurt (2006) reported that the addition of chicken and turkey breasts improved the processing quality of beef and therefore suggested that the optimal level of beef (M. semimembranosus), chicken and turkey was $0-23 \%, 9-30 \%$ and $53-91 \%$, respectively. Additionally, chicken breast increased the $\mathrm{pH}$ value of emulsion, resulting in the improvement of myofibrillar protein solubility. Thus, the use of chicken breast for manufacturing meat products is expected to result in physicochemical and textural properties. In terms of the sensory aspect, the taste and flavor of chicken were associated with being juicy, sour, sweet and umami (Maughan and Martini, 2012). Although both the pork loin and chicken breast have a lower fat content, there is little information available in the literature related to the effect of mixing ratio between pork loin and chicken breast on meat product.

Therefore, the objective of this study was to determine the changes in the processing quality using meat homogenates prepared with various mixing ratio between pork loin and chicken breast, based on the obtained best result, as well as to evaluate the textural and sensory properties of emulsion sausages formulated with pork loin and chicken breast.

\section{Materials and Methods}

\section{Preparation of raw materials}

Pork loin (M. longissimus dorsi) and chicken breast ( $M$. pectoralis major) in fresh broilers (Arbor acre strain, 5 wk of age, approximately $1.5-2.0 \mathrm{~kg}$ live weight) muscles after post-mortem $24 \mathrm{~h}$ were obtained from a local market. Pork back fat was also collected. All subcutaneous and inter-muscular fat were removed from the fresh pork loinand chicken breast. The pork loin, chicken breast, and back fat were initially ground using a meat grinder (PM-
70, Mainca, Spain) equipped with $8 \mathrm{~mm}$ plate. The ground chicken breast, pork loin, and pork back fat were packaged with Nylon/PE film, and used on the day.

\section{Experiment 1 (meat homogenates)}

All meat homogenates were composed by $80 \%$ raw meat, $20 \%$ ice, and $1.5 \% \mathrm{NaCl}$. And each sample batch consisted of five mixing ratio between ground pork loin and chicken breast as 100:0 (based on total sample composition $80 \%$ and $0 \%$ ), $70: 30$ (56\% and $24 \%$ ), 50:50 (40\% and $40 \%), 30: 70$ (24\% and 56\%), and 0:100 (0\% and $80 \%$ ).The mixture from each batch was homogenized using a meat blender for $3 \mathrm{~min}$. All meat homogenates were then placed in Nylon/PE film, and stored at $4^{\circ} \mathrm{C}$ during analysis. To evaluate the effect of mixing ratio between pork loin and chicken breast on processing quality, the $\mathrm{pH}$ value, color, salt soluble protein solubility, and cooking loss were determined.

\section{Experiment 2 (emulsion sausages)}

Emulsion sausages were produced with the formulation are given in Table 1. Total five mixing ratio between ground pork loin and chicken breast was used as 100:0 (based on total sample weight $70 \%$ and $0 \%$ ), $70: 30$ (49\% and $21 \%$ ), $50: 50$ (35\% and $35 \%), 30: 70$ (21\% and $49 \%$ ), and $0: 100$ $(0 \%$ and $70 \%)$. For each batch $(3 \mathrm{~kg})$ of the sausage, meat, fat, ice, and other ingredients were emulsified by using a bowl cutter (Nr-963009, Scharfen, Germany). After emulsification, all batters were stuffed into collagen casings (\#240, NIPPI Inc., Japan; approximate $25 \mathrm{~mm}$ diameter) by using a stuffer (IS-8, Sirman, Italy). The sausages were heated at $80^{\circ} \mathrm{C}$ until the core temperature of $75^{\circ} \mathrm{C}$. The emulsion sausages were used to analysis textural and sensory properties on the day.

\section{pH measurements}

The $\mathrm{pH}$ values of sample were determined with a $\mathrm{pH}$

Table 1. Formulation of emulsion sausages prepared with pork loin and chicken breast

\begin{tabular}{cccccc}
\hline \hline \multirow{2}{*}{ Ingredients (\%, w/w) } & \multicolumn{5}{c}{ Mixing ratio (pork loin / chicken breast) } \\
\cline { 2 - 6 } & $100 / 0$ & $70 / 30$ & $50 / 50$ & $30 / 70$ & $0 / 100$ \\
\hline Pork loin & 70 & 49 & 35 & 21 & 0 \\
Chicken breast & 0 & 21 & 35 & 15 & 70 \\
Back fat & 15 & 15 & 15 & 15 & 15 \\
Ice & 15 & 15 & 100 & 100 & 15 \\
\hline Total & 100 & 100 & 1.5 & 1.5 & 100 \\
\hline NPS & 1.5 & 0.3 & 0.3 & 0.3 & 0.3 \\
Sodium tri-polyphosphate & 0.3 & 0.05 & 0.05 & 0.05 & 0.05 \\
Ascorbic acid & 0.05 & &
\end{tabular}

1)NPS: nitrite pickled salt (99.4:0.6). 
meter (Model 340, Mettler-Toledo GmbH, Switzerland). The $\mathrm{pH}$ values of samples were measured by blending a $5 \mathrm{~g}$ sample with $50 \mathrm{~mL}$ distilled water for $60 \mathrm{~s}$ in a homogenizer at 8,000 rpm (Ultra-Turrax SK15, Janke \& Kunkel, Germany).

\section{Instrumental color evaluation}

Instrumental color were determined using a colorimeter (Minolta Chroma meter CR-210, Japan; illuminate C, calibrated with a white plate, $\mathrm{CIE} \mathrm{L}^{*}=+97.83, \mathrm{CIE} \mathrm{a}^{*}=-0.43$, $\left.\mathrm{CIE} \mathrm{b}^{*}=+1.98\right)$. Five measurements for each sampleon surface of meat homogenates and emulsions sausages were taken. CIE L* (lightness), CIE a* (redness), and CIE $\mathrm{b}^{*}$ (yellowness) values were recorded.

\section{Cooking loss}

Allmeat homogenates were cooked using a water bathat $80^{\circ} \mathrm{C}$ for until the targeted core temperature reached $75^{\circ} \mathrm{C}$. Cooking loss was determined by calculating the weight differences before and after cooking.

\section{Salt soluble protein solubility}

The solubility of the salt soluble (myofibrillar) protein was determined following the modification of procedures described by Saffle and Galbreath (1964). A 5 g sample was blended with $50 \mathrm{~mL} \mathrm{3 \%}$ sodium chloride solution at 14,000 rpm for 2 min using homogenizer (AM-7, Nihonseiki Kaisha, Japan). The mixture was centrifuged at 3,000 rpm for $15 \mathrm{~min}$. The protein concentration of supernatant was determined using the biuret method (Gornall et al., 1949) and using bovine serum albumin (Sigma Chemical Co., USA).

\section{Apparent viscosity}

Apparent viscosity of meat emulsion was measured in triplicate with a rotational viscometer (HAKKE Viscotester ${ }^{8}$ 550, Thermo Electron Corporation, Karlsruhe, Germany) at $10 \mathrm{rpm}$. The standard cylinder sensor (SV-2) was positioned in a $25 \mathrm{~mL}$ metal cup filled with batter and allowed to rotate under a constant shear rate $(1 / \mathrm{s})$ for $60 \mathrm{~s}$ before each reading was taken. The temperature of each sample at the time $\left(18 \pm 1^{\circ} \mathrm{C}\right)$ of testing was also recorded (Choi et al., 2010).

\section{Texture profile analysis (TPA)}

Texture profile analysis was performed at room temperaturewith a texture analyzer (TA-XT2i, Stable Micro Systems Ltd., England). The cooked samples under above mentioned condition were cooled to room temperature at $25^{\circ} \mathrm{C}$ for $3 \mathrm{~h}$. Before analysis, the cooked sausages were allowed to equilibrate to room temperature. Samples were taken from the central portion of each emulsion sausage. The conditions of texture analysis were as follows: pretest speed $2.0 \mathrm{~mm} / \mathrm{s}$, post-test speed $5.0 \mathrm{~mm} / \mathrm{s}$, maximum load $2 \mathrm{~kg}$, head speed $2.0 \mathrm{~mm} / \mathrm{s}$, distance $8.0 \mathrm{~mm}$, force $5 \mathrm{~g}$ (Choi et al., 2010). Value for hardness, springiness (ratio), cohesiveness, gumminess, and chewiness were determined as described by Bourne (1978).

\section{Sensory evaluation}

Each treatment was evaluated in three sessions (replications) conducted on different days. Emulsion sausages formulated with various mixing ratio between pork loin and chicken breast were assessed for sensory properties by a 12 member trained panel (ASTM, 1981), between the ages 20 and 35. Each samples heated by microwave for $15 \mathrm{~s}$, cut into $2.5 \mathrm{~cm}$ cubes, were served to the panelists in random order, and the sensory evaluations were performed by the panelists under fluorescence lighting. Panelists were instructed to cleanse their palates between samples using warm water. The appearance, color, flavor, tenderness, fatness, and overall acceptance ( $1=$ extremely undesirable, $9=$ extremely desirable), juiciness ( $1=$ extremely dry, $9=$ extremely juicy), residual flavor and umami $(1=$ much too weak, 9=much too intense) of the samples were evaluated.

\section{Statistical analysis}

The experiments were replicated three times, and values represent the mean and standard deviation. Analysis of variance was conducted using the general linear model (GLM) procedure of the SPSS 18.0 software (SPSS Inc, USA). Also, the linear regression equations among $\mathrm{pH}$ value, salt soluble protein solubility, and cooking loss were calculated with SPSS.For sensory evaluation data, the principle component analysis (PCA) was performed on the recorded data to categorize the sensory properties of emulsion sausages. SPSS 18.0 software was also used for PCA analysis. Duncan's multiple range test was used to compare the mean values $(p<0.05)$.

\section{Results and Discussion}

\section{pH value and color parameters of meat homoge- nates}

The effect of mixing ratio between pork loin and chicken breast on $\mathrm{pH}$ value and color parameters of meat homogenates is shown in Table 2. In this study, the $\mathrm{pH}$ values 
Table 2. Effect of mixing ratio between pork loin and chicken breast on $\mathrm{pH}$ value and color parameters of meat homogenates

\begin{tabular}{|c|c|c|c|c|c|c|}
\hline \multirow{2}{*}{ Type } & \multirow{2}{*}{ Traits } & \multicolumn{5}{|c|}{ Mixing ratio (pork loin / chicken breast) } \\
\hline & & $100 / 0$ & $70 / 30$ & $50 / 50$ & $30 / 70$ & $0 / 100$ \\
\hline \multirow{4}{*}{ Raw } & $\mathrm{pH}$ & $5.79 \pm 0.06^{1) c, y}$ & $5.82 \pm 0.05^{\mathrm{c}, y}$ & $5.90 \pm 0.04^{\mathrm{b}, \mathrm{y}}$ & $5.93 \pm 0.04^{\mathrm{b}, \mathrm{y}}$ & $6.01 \pm 0.03^{\mathrm{a}, \mathrm{y}}$ \\
\hline & CIE L* & $66.88 \pm 2.43^{b, x}$ & $61.94 \pm 1.58^{\mathrm{b}, \mathrm{y}}$ & $60.22 \pm 3.10^{\text {ab,y }}$ & $59.98 \pm 1.91^{\mathrm{ab}, \mathrm{y}}$ & $71.65 \pm 1.37^{\mathrm{a}, \mathrm{y}}$ \\
\hline & CIE a* & $11.71 \pm 0.21^{\mathrm{a}, \mathrm{x}}$ & $9.48 \pm 0.64^{\mathrm{b}, \mathrm{x}}$ & $8.79 \pm 0.93^{\mathrm{b}, \mathrm{x}}$ & $6.04 \pm 1.15^{\mathrm{c}, \mathrm{x}}$ & $2.59 \pm 0.27^{\mathrm{d}, \mathrm{x}}$ \\
\hline & CIE b* & $12.88 \pm 0.97^{\mathrm{a}, \mathrm{x}}$ & $12.60 \pm 1.33^{\mathrm{a}, \mathrm{x}}$ & $12.76 \pm 1.24^{\mathrm{a}, \mathrm{x}}$ & $10.91 \pm 1.43^{\mathrm{b}}$ & $10.15 \pm 1.65^{\mathrm{b}}$ \\
\hline \multirow{4}{*}{ Cooked } & $\mathrm{pH}$ & $6.01 \pm 0.02^{\mathrm{d}, \mathrm{x}}$ & $6.03 \pm 0.01^{\mathrm{c}, \mathrm{x}}$ & $6.10 \pm 0.02^{b, x}$ & $6.11 \pm 0.02^{\mathrm{b}, \mathrm{x}}$ & $6.15 \pm 0.04^{\mathrm{a}, \mathrm{x}}$ \\
\hline & CIE L* & $77.05 \pm 0.25^{\mathrm{e}, \mathrm{x}}$ & $78.95 \pm 0.29^{\mathrm{d}, \mathrm{x}}$ & $79.59 \pm 0.35^{\mathrm{c}, \mathrm{x}}$ & $81.83 \pm 0.19^{b, x}$ & $84.31 \pm 0.35^{\mathrm{a}, \mathrm{x}}$ \\
\hline & CIE $a^{*}$ & $7.14 \pm 0.25^{\mathrm{a}, \mathrm{y}}$ & $5.52 \pm 0.10^{\text {by }}$ & $4.19 \pm 0.15^{\mathrm{c}, \mathrm{y}}$ & $3.22 \pm 0.50^{\mathrm{d}, \mathrm{y}}$ & $2.15 \pm 0.53^{\mathrm{e}, \mathrm{y}}$ \\
\hline & CIE b* & $9.36 \pm 0.25^{\mathrm{d}, \mathrm{y}}$ & $9.66 \pm 0.19^{\mathrm{c}, \mathrm{y}}$ & $10.16 \pm 0.06^{\mathrm{b}, \mathrm{y}}$ & $10.28 \pm 0.23^{\mathrm{a}}$ & $10.32 \pm 0.16^{\mathrm{a}}$ \\
\hline
\end{tabular}

${ }^{10}$ All values are mean \pm standard deviation of three replicates.

${ }^{\mathrm{a}-\mathrm{e}}$ Means within a row (among treatments) with different letters are significantly different $(p<0.05)$.

${ }^{\mathrm{x}, \mathrm{y}}$ Means between raw and cooked sample within each treatment different letters are significantly different $(p<0.05)$.

of pork loin and chicken breast were 5.73 and 6.00 , respectively. In previous studies, the $\mathrm{pH}$ value of normal pork loin was 5.74 (Joo et al., 1999), and the $\mathrm{pH}$ value of normal chicken breast was 6.02 (Barbut et al., 2005). In both meat homogenates after or before cooking, the $\mathrm{pH}$ value increased with increasing the added levels of chicken breast in meat homogenates. Further, the meat homogenates formulated with only pork loin showed the lowest $\mathrm{pH}$ value among all treatments $(p<0.05)$. Similarly, Zorba and Kurt (2006) reported that the increase in chicken breast of meat homogenates prepared with beef resulted in an increased $\mathrm{pH}$ value. In addition, the $\mathrm{pH}$ value increased after cooking in all treatments $(p<0.05)$. The $\mathrm{pH}$ range of raw meat homogenates was 5.79-6.01, whereas that after cooking was 6.01-6.15. According to Forrest et al. (1975), the reason for the increased $\mathrm{pH}$ value in meat emulsion due to cooking is related to the exposure of imidazolium, which is an alkaline-residue in histidine amino acid. The $\mathrm{pH}$ of meat is greatly associated with water retention and textural properties of the final product (Tornberg, 2005); thus, our result is expected to cause an improvement in the technological properties of meat homogenates with added chicken breast due to the high $\mathrm{pH}$ value of chicken breast.

Color characteristics of the muscle, or reddish color, primarily depend on the myoglobin content and chemical state of the myoglobin molecule (Lawrie, 1998). In addition, King and Whyte (2006) concluded that the formation of cooked color in meat products was affected by $\mathrm{pH}$, animal species, meat parts, packaging method, cooking method, fat content and additives. Kranene et al. (1999) reported that myoglobin was not detected in the pectoralis broiler muscle, whereas Newcom et al. (2004) noted that pork loin contains $0.62-0.95 \mathrm{mg} / \mathrm{g}$ of soluble myoglobin. In this study, the CIE L* value (lightness) increased with increasing the added level of chicken breast in meat homogenates; however, the CIE a* (redness) and CIE b* (yellowness) values decreased. The result of the redness is greatly related to the lower myoglobin content of chicken breast muscle as compared to that of pork loin. In cooked meat homogenates, there was a similar tendency in the color characteristics of raw meat homogenates among each mixing ratio. Similarly, Fletcher et al. (2000) reported that increased lightness and yellowness and decreased redness were observed for chicken breast after thermal treatment and therefore, suggested that the color of cooked chicken breast highly correlated with the $\mathrm{pH}$ value of raw meat. However, thermal processing, a form of cooking, is the most greatest factor affecting the differences between the color of raw and cooked chicken breast. Thus, increased lightness and decreased redness of meat homogenates due to cooking were observed for all treatments regardless of the mixing ratio between pork loin and chicken breast.

\section{Cooking loss and salt soluble protein solubility of meat homogenates}

The effect of mixing ratio between pork loin and chicken breast on cooking loss and salt soluble protein solubility of meat homogenates is presented in Table 3. An increase in chicken breast added in meat homogenates improved the cooking loss. The addition of chicken breast above $50 \%$ showed a lower cooking loss than the control, which is formulated with only pork loin $(p<0.05)$. Moreover, the meat homogenate prepared with only chicken breast showed the lowest cooking loss among all treatments $(p<0.05)$. The structure of the restructured meat is formed with an extraction of muscle protein along with the addition of salt, and the stable meat structure could minimize the release of moisture and fat during thermal treatment (Asghar et al., 1985). Thus, moisture and fat retention in meat homogenates is affected by the solubility 
Table 3. Effect of mixing ratio between pork loin and chicken breast on cooking loss and salt soluble protein solubility of meat homogenates

\begin{tabular}{cccccc}
\hline \hline \multirow{2}{*}{ Traits } & \multicolumn{5}{c}{ Mixing ratio (pork loin/ chicken breast) } \\
\cline { 2 - 5 } & $100 / 0$ & $70 / 30$ & $50 / 50$ & $30 / 70$ & $0 / 100$ \\
\hline Cooking loss (\%) & $20.38 \pm 0.87^{1 \text { )a }}$ & $20.16 \pm 0.75^{\mathrm{a}}$ & $18.21 \pm 0.54^{\mathrm{b}}$ & $17.62 \pm 0.73^{\mathrm{b}}$ & $16.44 \pm 1.73^{\mathrm{c}}$ \\
$\begin{array}{c}\text { Salt soluble protein } \\
\text { solubility (mg/g) }\end{array}$ & $18.14 \pm 0.36^{\mathrm{c}}$ & $18.57 \pm 0.20^{\mathrm{b}}$ & $18.57 \pm 0.32^{\mathrm{b}}$ & $18.74 \pm 0.23^{\mathrm{b}}$ & $19.54 \pm 0.12^{\mathrm{a}}$ \\
\hline
\end{tabular}

${ }^{1)}$ All values are mean \pm standard deviation of three replicates.

${ }^{\mathrm{a}-\mathrm{c}}$ Means within a row(among treatments) with different letters are significantly different $(p<0.05)$.

of muscle proteins. In this study, it is clear that the $\mathrm{pH}$ value of meat homogenates correlates with that of salt soluble protein solubility (Fig. 1a). Additionally, by increasing the amounts of chicken breast, salt soluble protein solubility increased (Fig. 1b). The solubility of myofibrillar proteins is the most important factor affecting cooking loss and textural properties. In previous studies, the $\mathrm{pH}$ value, salt level and extracting condition influenced the solubility of myofibrillar proteins (Gillett et al., 1977; Tornberg, 2005). According to Lesiów and Xiong (2003), the ability to form chicken muscle protein was maximized at $\mathrm{pH}$ 6.0. The gel formation with muscle protein is related to the $\mathrm{pH}$ value of raw meat, animal species and part, the characteristics of muscle fiber, ionic strength,
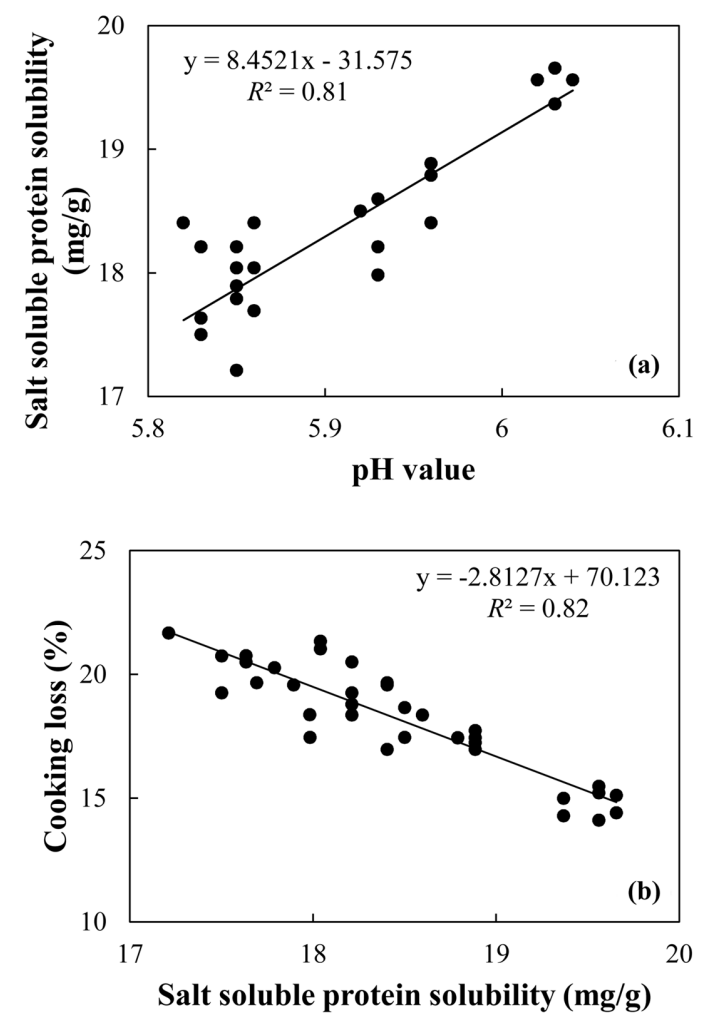

Fig. 1. Relationship between salt soluble protein solubility and cooking loss of meat homogenates formulated with various mixing ratio between pork loin and chicken breast. type and level of added salt, and thermal condition (Lan et al., 1995; Samejima et al., 1992; Tornberg, 2005). Thus, our result suggested that the improvement of salt soluble protein solubility due to a high $\mathrm{pH}$ of chicken breast added could contribute to the formation of more stable structured cooked meat homogenates. Similarly, Zorba and Kurt (2006) indicated that the high $\mathrm{pH}$ of chicken breast led to an improvement of emulsion functionality, such as emulsion stability and capacity.

\section{Apparent viscosity}

The apparent viscosity of meat homogenates formulated with various mixing ratios between pork loin and chicken breast is shown in Fig. 2. The meat homogenates prepared with only pork loin showed a lower apparent viscosity compared to the meat homogenates containing chicken breast. Moreover, the increase in the added amount of chicken breast clearly increased the apparent viscosity

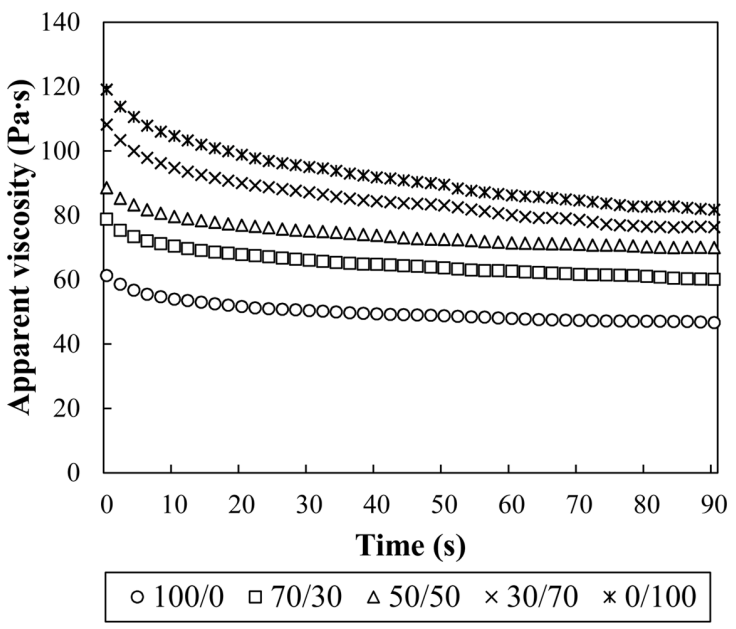

Fig. 2. Changes in apparent viscosity of meat homogenates formulated with various mixing ratio between pork loin and chicken breast stirred for 90 sec. $(\bigcirc)$, meat homogenates formulated with $100 \%$ pork loin; $(\square)$, meat homogenates formulated with $70 \%$ pork loin and $30 \%$ chicken breast; $(\triangle)$, meat homogenates formulated with $50 \%$ pork loin and $50 \%$ chicken breast; $(\times)$, meat homogenates formulated with $30 \%$ pork loin and $70 \%$ chicken breast; and $\left({ }^{*}\right)$ meat homogenates formulated with $100 \%$ chicken breast. 
of meat homogenates. Cofrades et al. (1993) suggested that the increase in protein content and $\mathrm{pH}$ value increased the viscosity of actomyosin extracted from pork loin and chicken breast regardless of animal species. Apparent viscosity, which means the emulsion stability composed of moisture, protein and lipid, is a useful factor predicting the textural properties of the final product. Thus, the improvement of textural properties due to the addition of chicken breast is expected with increased apparent viscosity.

\section{Textural properties of emulsion sausages}

The effect of mixing ratio between pork loin and chicken breast on the textural properties of emulsion sausages is presented in Table 4. Increasing the added amount of chicken breast led to a decrease in hardness, gumminess and chewiness of emulsion sausages. In Table 3, the meat homogenates formulated with chicken breast above 50\% showed a significantly lower cooking loss than that prepared with only pork loin. The significant decrease in hardness resulted from the addition of chicken breast above $50 \%$. In terms of springiness, however, emulsion sausages prepared with $50 \%$ pork loin and $50 \%$ chicken breast showed a higher springiness than emulsion sausages for- mulated with $100 \%$ pork loin $(p<0.05)$. According to Ziegler et al. (1987), a decrease in moisture level resulted in increased hardness and fracturability, but decreased springiness. The addition of chicken breast contributing to a decrease in cooking loss resulted from a high amount of moisture in emulsion sausages. However, there were no differences in cohesiveness among all treatments $(p>0.05)$. Farouk et al. (2002) suggested that the solubility of sarcoplasmic proteins greatly affected cohesiveness. In this study, all treatments showed a similar sarcoplasmic protein solubility (data not shown). Further, Ziegler et al. (1987) suggested that the moisture content had no influence on cohesiveness. Consequently, the addition of chicken breast above $50 \%$ could contribute to a more soft and flexible texture of emulsion sausage, and such effect might be related to the improvement of cooking loss owing to the addition of chicken breast.

\section{Sensory properties of emulsion sausages}

The sensory properties of emulsion sausages formulated with various mixing ratios between pork loin and chicken breast are portrayed in Table 5. The statistical results indicated that the mixing ratio between pork loin and chicken breast had no influence on appearance, flavor and fatness

Table 4. Effect of mixing ratio between pork loin and chicken breast on textural properties of emulsion sausages

\begin{tabular}{|c|c|c|c|c|c|}
\hline \multirow{2}{*}{ Traits } & \multicolumn{5}{|c|}{ Mixing ratio (pork loin / chicken breast) } \\
\hline & $100 / 0$ & $70 / 30$ & $50 / 50$ & $30 / 70$ & $0 / 100$ \\
\hline Hardness & $1.02 \pm 0.08^{1) \mathrm{a}}$ & $0.98 \pm 0.03^{\mathrm{a}}$ & $0.89 \pm 0.08^{b}$ & $0.81 \pm 0.07^{\mathrm{c}}$ & $0.52 \pm 0.04^{\mathrm{d}}$ \\
\hline Springiness & $0.72 \pm 0.02^{\mathrm{c}}$ & $0.73 \pm 0.02^{\mathrm{c}}$ & $0.76 \pm 0.02^{b}$ & $0.76 \pm 0.03^{b}$ & $0.80 \pm 0.02^{\mathrm{a}}$ \\
\hline Cohesiveness & $0.49 \pm 0.05$ & $0.49 \pm 0.04$ & $0.47 \pm 0.06$ & $0.46 \pm 0.03$ & $0.46 \pm 0.07$ \\
\hline Gumminess & $0.50 \pm 0.06^{\mathrm{a}}$ & $0.48 \pm 0.06^{\mathrm{a}}$ & $0.42 \pm 0.06^{\mathrm{b}}$ & $0.37 \pm 0.04^{b}$ & $0.24 \pm 0.03^{c}$ \\
\hline Chewiness & $0.36 \pm 0.04^{\mathrm{a}}$ & $0.35 \pm 0.05^{\mathrm{a}}$ & $0.32 \pm 0.05^{\mathrm{ab}}$ & $0.28 \pm 0.03^{\mathrm{b}}$ & $0.19 \pm 0.02^{\mathrm{c}}$ \\
\hline
\end{tabular}

${ }^{1)}$ All values are mean \pm standard deviation of three replicates.

${ }^{\mathrm{a}-\mathrm{d}}$ Means within a row(among treatments) with different letters are significantly different $(p<0.05)$.

Table 5. Effect of mixing ratio between pork loin and chicken breast on sensory properties of emulsion sausages

\begin{tabular}{clllll}
\hline \hline Traits & \multicolumn{5}{c}{ Mixing ratio (pork loin / chicken breast) } \\
\cline { 2 - 6 } & $100 / 0$ & $70 / 30$ & $50 / 50$ & $30 / 70$ & $0 / 100$ \\
\hline Appearance & $8.50 \pm 0.67^{2)}$ & $8.42 \pm 0.79$ & $8.17 \pm 0.39$ & $8.33 \pm 0.65$ & $8.33 \pm 0.65$ \\
Color & $8.42 \pm 0.79^{\mathrm{a}}$ & $8.25 \pm 0.75^{\mathrm{ab}}$ & $7.95 \pm 0.75^{\mathrm{b}}$ & $7.88 \pm 0.47^{\mathrm{bc}}$ & $7.58 \pm 0.67^{\mathrm{c}}$ \\
Flavor & $7.50 \pm 1.09$ & $7.67 \pm 0.89$ & $8.17 \pm 0.94$ & $8.25 \pm 0.75$ & $8.25 \pm 0.87$ \\
Juiciness & $6.83 \pm 0.94^{\mathrm{b}}$ & $7.17 \pm 0.94^{\mathrm{ab}}$ & $7.58 \pm 1.00^{\mathrm{ab}}$ & $7.92 \pm 0.79^{\mathrm{a}}$ & $7.92 \pm 0.79^{\mathrm{a}}$ \\
Tenderness & $6.83 \pm 0.94^{\mathrm{b}}$ & $7.33 \pm 0.89^{\mathrm{ab}}$ & $7.75 \pm 0.62^{\mathrm{a}}$ & $7.67 \pm 0.65^{\mathrm{a}}$ & $7.67 \pm 0.78^{\mathrm{a}}$ \\
Residual flavor & $7.00 \pm 0.85^{\mathrm{b}}$ & $7.17 \pm 0.58^{\mathrm{ab}}$ & $7.67 \pm 0.89^{\mathrm{ab}}$ & $7.67 \pm 0.65^{\mathrm{ab}}$ & $7.83 \pm 0.83^{\mathrm{a}}$ \\
Fatness & $7.75 \pm 1.14$ & $7.67 \pm 1.07$ & $7.58 \pm 1.08$ & $7.50 \pm 1.17$ & $7.42 \pm 1.44$ \\
Umami & $6.75 \pm 1.29^{\mathrm{b}}$ & $7.00 \pm 1.28^{\mathrm{ab}}$ & $7.33 \pm 1.37^{\mathrm{ab}}$ & $7.42 \pm 1.24^{\mathrm{a}}$ & $7.67 \pm 1.30^{\mathrm{a}}$ \\
Overall acceptance & $7.17 \pm 0.83^{\mathrm{c}}$ & $7.50 \pm 0.80^{\mathrm{bc}}$ & $8.25 \pm 0.87^{\mathrm{a}}$ & $8.25 \pm 0.75^{\mathrm{a}}$ & $8.08 \pm 0.67^{\mathrm{ab}}$ \\
\hline
\end{tabular}

${ }^{1)}$ Traits: appearance, color, flavor, tenderness, fatness, and overall acceptance ( $1=$ extremely undesirable, $9=$ extremely desirable), juiciness (1=extremely dry, $9=$ extremely juicy), residual flavor and umami ( $1=$ much too weak, $9=$ much to intense).

${ }^{2)}$ All values are mean \pm standard deviation of three replicates.

${ }^{\mathrm{a}-\mathrm{c}}$ Means within a row(among treatments) with different letters are significantly different $(p<0.05)$. 
$(p>0.05)$. In color satisfaction, the increase in the added level of chicken breast in emulsion sausages resulted in a decline in color score. This result might be associated with the decreased redness following the addition of chicken breast, which was observed with an instrument color evaluation (Table 2). The emulsion sausages containing chicken breast above $70 \%$ showed significantly higher sensory scores for juiciness, tenderness and umami than those of emulsion sausage formulated with only pork loin $(p<0.05)$. Also, the addition of chicken breast in emulsion sausage led to an increase in the score for residual flavor. As a related study, Whiting and Jenkins (1981) reported that frankfurters prepared with chicken showed the highest sensory satisfaction as compared to those made with rabbit or beef. In order to determine the main component for explaining the sensory properties of emulsion sausages, a principle component analysis (PCA) was performed (Fig. 3). As a result, the overall acceptance of emulsion sausages highly correlated with tenderness, umami taste and residual flavor $(p<0.05)$. Recently, according to Maughan and Martini (2012), the sensory characteristics of chicken meat in meat homogenates containing beef and chicken were brothy, juicy, salt, sour, sweet and umami. In this study, an increase in the added amount of chicken breast contributed to a rich umami taste and deeper flavor in emulsion sausages, thereby resulting in a high overall acceptance score in the formulation of $0-30 \%$ pork loin and $70-100 \%$ chicken breast.

In conclusion, the addition of chicken breast in mixed meat homogenates with pork loin decreased the cooking loss resulting from an increased salt soluble protein solubility due to a high $\mathrm{pH}$ value of chicken breast. Moreover,

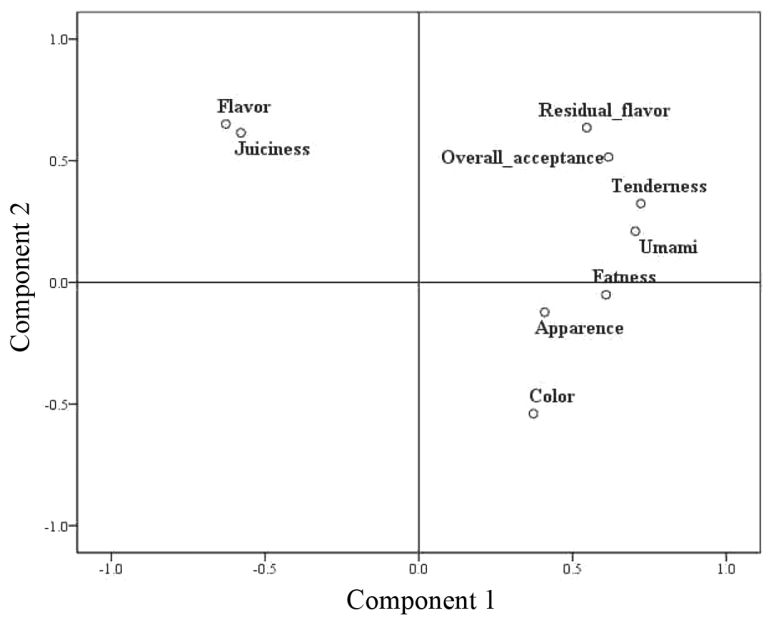

Fig. 3. Principle component analysis (PCA) for plot based on sensory properties of emulsion sausages formulated with pork loin and chicken breast. the effect greatly depended on the added levels of chicken breast. For these reasons, emulsion sausages formulated with chicken breast above $50 \%$ could provide a more soft and flexible texture. The sensory characteristics of chicken breast in emulsion sausages might be associated with residual flavor, tenderness and umami taste. Considering the color aspect, the optimal mixing ratio between pork loin and chicken breast for enhancing the technological and sensory properties of meat product was $0-30 \%$ and $70-100 \%$, respectively.

\section{Acknowledgements}

This research was supported by Technology Development Program (608001-05-4-SB310) for Ministry of Agriculture, Food and Rural Affairs, Republic of Korea.

\section{References}

1. Asghar, A., Samejima, K., Yasui, T., and Henrickson, R. L. (1985) Functionality of muscle proteins in gelation mechanisms of structured meat products. Crit. Rev. Food Sci. 22, 27106.

2. ASTM. (1981) American Society for Testing and Materials. Guidelines for the selection and training of sensor and panel members. ASTM STP 758, ASTM Philadelphia, 3-33.

3. Barbut, S., Zhang, L., and Marcone, M. (2005) Effects of pale, normal, and dark chicken breast meat on microstructure extractable proteins, and cooking of marinated fillets. Poult. Sci. 84,797-802.

4. Bourne, M. C. (1978) Texture profile analysis. Food Technol. 32, 62-66.

5. Choi, Y. S., Choi, J. H., Han, D. J., Kim, H. Y., Lee, M. A., Kim, H. W., Lee, J. W., Chung, H. J., and Kim, C. J. (2010) Optimization of replacing pork back fat with grape seed oil and rice bran fiber for reduced-fat meat emulsion systems. Meat Sci. 84, 212-218.

6. Cofrades, S., Careche, M., Carballo, J., and Colmenero, F. J. (1993) Protein concentration, $\mathrm{pH}$ and ionic strength affect apparent viscosity of actomyosin. J. Food Sci. 58, 1269-1272.

7. Dorado, M., Martín Gómez, E. M., Jiménez-Colmenero, F., and Masoud, T. A. (1999) Cholesterol and fat contents of Spanish commercial pork cuts. Meat Sci. 51, 321-323.

8. Farouk, M. M., Wieliczko, K., Lim, R., Turnwald, S., and MacDonald, G. A. (2002) Cooked sausage batter cohesiveness as affected by sarcoplasmic proteins. Meat Sci. 61, 8590.

9. Fletcher, D. L., Qiao, M., and Smith, D. P. (2000) The relationship of raw broiler breast meat color and $\mathrm{pH}$ to cooked meat color and pH. Poultry Sci. 79, 784-788.

10. Forrest, J. C., Aberle, E. D., Hedrick, H. B., Judge, M. D., and Merkel, R. A. (1975) Principles of meat processing. Principles of meat science. W. H. Freeman and Company. San Francisco, CA. pp. 190-226. 
11. Gillett, T. A., Meiburg, D. E., Brown, C. L., and Simon, S. (1977) Parameters affecting meat protein extraction and interpretation of model system data for meat emulsion formation. J. Food Sci. 42, 1606-1610.

12. Gornall, A. G., Bardawill, C. J., and David, M. M. (1949) Determination of serum proteins by means of the Biuret reaction. J. Biol. Chem. 177, 751-766.

13. Hämäläinen, N. and Pette, D. (1995) Patterns of myosin isoforms in mammalian skeletal muscle fibres. Microsc. Res. Techniq. 30, 381-389.

14. Joo, S. T., Kauffman, R. G., Kim, B. C., and Park, G. B. (1999) The relationship of sarcoplasmic and myofibrillar protein solubility to colour and water-holding capacity in porcine longissimus muscle. Meat Sci. 52, 291-297.

15. Karlsson, A. H., Klont, R. E., and Fernandez, X. (1999) Skeletal muscle fibres as factors for pork quality. Livest. Prod. Sci. 60, 255-269.

16. King, N. J. and Whyte, R. (2006) Does it look cooked? a review of factors that influence cooked meat color. J. Food Sci. 71, R31-R40.

17. Klont, R. E., Brocks, L., and Eikelenboom, G. (1998) Muscle fibre type and meat quality. Meat Sci. 49, S219-S229.

18. Kranene, R. W., Van Kuppevelt, T. H., Goedhart, H. A., Veerkamp, C. H., Lambooy, E., and Veerkamp, J. H. (1999) Hemoglobin and myoglobin content in muscles of broiler chickens. Poultry Sci. 78, 467-476.

19. Lan, Y. H., Novakofski, J., McCusker, R. H., Brewer, M. S., Carr, T. R., and McKeith, F. K. (1995) Thermal gelation myofibrils from pork, beef, fish, chicken and turkey. J. Food Sci. 60, 941-945.

20. Lawrie, R. A. (1998) Lawrie's meat science. $6^{\text {th }}$ ed, Woodhead Publishing Limited, Cambridge, England, pp. 212-219.

21. Lesiów, T. and Xiong, Y. L. (2003) Chicken muscle homogenate gelation properties: effect of $\mathrm{pH}$ and muscle fiber type. Meat Sci. 64, 399-403.
22. Maughan, C. and Martini, S. (2012) Identification and quantification of flavor attributes present in chicken, lamb, pork, beef, and turkey. J. Food Sci. 77, S115-S121.

23. Newcom, D. W., Stalder, K. J., Baas, T. J., Goodwin, R. N., Parrish, F. C., and Wiegand, B. R. (2004) Breed differences and genetic parameters of myoglobin concentration in porcine longissimus muscle. J. Anim. Sci. 82, 2264-2268.

24. Saffle, R. L. and Galbreath, J. W. (1964) Quantitative determination of salt-soluble protein in various types of meat. Food Technol. 18, 1943-1944.

25. Samejima, K., Lee, N. H., Ishioroshi, M., and Asghar, A. (1992) Protein extractability and thermal gel formability of myofibrils isolated from skeletal and cardiac muscles at different post-mortem periods. J. Sci. Food Agric. 58, 385-393.

26. Smith, D. P. and Fletcher, D. L. (1987) Chicken breast muscle fiber type and diameter as influenced by age and intramuscular location. Poultry Sci. 67, 908-913.

27. Tornberg, E. (2005) Effects of heat on meat proteins - Implication on structure and quality of meat products. Meat Sci. 70, 493-508.

28. Tsai, R., Cassens, R. G., and Briskey, E. J. (1972) The emulsifying properties of purified muscle proteins. J. Food Sci. 37, 286-288.

29. Whiting, R. C. and Jenkins, R. K. (1981) Comparison of rabbit, beef, and chicken meats for functional properties and frankfurter processing. J. Food Sci. 46, 1693-1696.

30. Ziegler, G. R., Rizvi, S. S. H., and Acton, J. C. (1987) Relationship of water content to textural characteristics, water activity, and thermal conductivity of some commercial sausages. J. Food Sci. 52, 901-905.

31. Zorba, Ö. and Kurt, Ş. (2006) Optimization of emulsion characteristics of beef, chicken and turkey meat mixtures in model system using mixture design. Meat Sci. 73, 611-618.

(Received 2014.1.3/Revised 2014.2.7/Accepted 2014.2.7) 